\title{
JUSTICE FOR ALL? \\ ISSUES FACED BY LINGUISTIC MINORITIES AND BORDER PATROL AGENTS DURING INTERPRETED ARRAIGNMENT INTERVIEWS
}

\author{
Claudia Angelelli \\ c.angelelli@hw.ac.uk \\ Heriot-Watt University
}

\begin{abstract}
The Tijuana (Mexico) - San Ysidro (San Diego County, CA) international border is the world's busiest port of entry. The US Customs and Border Protection Agency hires over 60,000 employees, 21,000 of whom are agents in the US Border Patrol. Several steps must be taken to become a border patrol agent, but being bilingual is not a pre-requisite.

In order to communicate with detainees, and interrogate them, the US Border Patrol Agency hires the services of Telephone Interpreting Companies. In this study I present segments of a 2 hour and fifty minute transcript that captures a typical border patrol agent /detainee interaction facilitated by an ad-hoc interpreter. I examine the power differentials between the interlocutors and the role played by the telephone interpreter in mitigating or reinforcing such power. After analyzing the interpreter's credentials and the border patrol linguistic needs, I specifically look at interpreter's linguistic behaviors that lead to a detention reversed during the trial. This study calls into question the construct of justice when serving the needs of culturally and linguistically diverse populations.
\end{abstract}

\section{Resumen}

La frontera internacional entre Tijuana (México) y San Ysidro (Condado de San Diego, California) es el puerto de entrada más activo del mundo. La agencia de Aduanas y Protección Fronteriza de los Estados Unidos (US Customs and Border Protection Agency) emplea a más de 60.000 personas, 21.000 de las cuales son agentes de la Patrulla Fronteriza de los Estados Unidos (US Border Patrol). Entre los diversos 
requisitos para el ejercicio de la función de patrulla fronteriza no se encuentra el ser bilingüe.

A la hora de comunicarse con las personas detenidas e interrogarlas, la Patrulla Fronteriza de los Estados Unidos contrata los servicios de empresas de interpretación telefónica. En este estudio se presentan varios segmentos de una transcripción de 2 horas y 50 minutos de duración que capta una interacción típica entre una persona detenida y un agente de la patrulla fronteriza, facilitada por una intérprete (ad-hoc) a través del teléfono. Se muestran las diferencias de poder entre los interlocutores y el papel del intérprete telefónico a la hora de mitigar o reforzar ese poder. Tras analizar las credenciales del intérprete y las necesidades lingüísticas de la patrulla fronteriza, este trabajo se centra específicamente en los comportamientos lingüísticos del intérprete, los cuales conducen a una detención posteriormente anulada en juicio. Este estudio cuestiona el constructo de la justicia a la hora de servir a las necesidades de poblaciones cultural y lingüísticamente diversas.

Keywords: Remote interpreting. Language access. Official transcript. Interpreter's performance. Interpreting quality.

Palabras clave: Interpretación remota, Derechos lingüísticos. Transcripción oficial. Actuación del intérprete. Calidad de la interpretación.

Manuscript received on July 27, 2014

and accepted for publication on September 9, 2014. 


\section{Introduction}

In the United States, as in many other countries of the world, the goal of the judicial system is to administer and serve justice. This lofty goal is stated in the Pledge of Allegiance ending with the phrase "... liberty and justice for all". Equality under the law is represented by Justitia, the Goddess of justice. She is blindfolded. In her left hand she holds the scales of justice and in her right hand the sword representing the force of law. In diverse societies such as the United States, justice for all is achieved across social differences (e.g., cultural, linguistic or racial). In this article, I present a case that illustrates the many challenges of reaching (or not reaching) the lofty goal of justice for all.

On July 6, 2012, two Border Patrol officers at a Southern border crossing in California apprehended an individual driving a commercial vehicle. While attempting to enter the United States, the vehicle was pulled aside for inspection and officers discovered methamphetamine inside. The driver and sole occupant of the vehicle was a monolingual Spanish-speaking male. He was charged with attempted smuggling of an illegal substance into the US. Because the two officers were monolingual English speakers, the linguistic barrier between the agents and the detainee hindered questioning and the use of an interpreter was required. With no interpreter available on site, the agents utilized a telephone interpreting service to conduct the arraignment interview. As a result of this interview, the detainee was sent to jail. The decision was appealed by the Public Defender. The sentence was reversed in the appeal. After two months in prison and after losing his right to work as a driver across the border, the detainee was set free. In this article we will look at examples of construction of evidence and assumptions of guilt that lead to a conviction based on the performance of the two monolingual border agents and the appointed "qualified interpreter". Examples come from a content analysis of the official transcription of the DVD captured during the arraignment interview and a comparative and contrastive analysis between the official transcript and the DVD itself that were given to the expert witness. This case raises important issues to be considered when administering justice for a culturally and linguistically diverse population. Among those issues are: the 
right of all parties involved in an arraignment interview to access information, the right to express oneself in one's language and to be understood by the other interlocutors via interpreting and the right of linguistic minorities to a certified (or "qualified" if no certification is available) interpreter.

\section{Review of the relevant literature}

\subsection{Language and interpreting: vehicles for accessing, blocking and constructing information}

The right to use one's native language within socially relevant official contexts is included within the fundamental human rights of every individual (Hamel 1995). According to van Dijk (2000), linguicism occurs when an individual is prohibited from communicating via his or her mother tongue, resulting in discrimination and marginalization. By denying an individual his or her right to communicate, he/she is excluded from public discourse. In this way, speakers of the dominant language control access to public discourse, processes, and services, while speakers of minority languages remain powerless. This power differential relegates non-speakers of the dominant language to an unequal, inferior status. During an arrest at the border, the Border Patrol agents control the discourse via use of the dominant language and thus hold the power. The Spanish-speaking detainee, by not speaking the societal language, is at a disadvantage. When he is not given the opportunity to represent himself in his native language and is unable to communicate adequately, he becomes a victim of linguistic discrimination.

In many cases, when a suspect does not speak or understand English, a bilingual police officer will perform interpreting duties. The use of police officers as interpreters during interrogations is in itself problematic and it also represents a breach of interpreting norms due to a conflict of interest (Berk-Seligson 2011). Police officers are, in general, unqualified to perform the duties of interpreter and many times lack the linguistic skills required. In Berk-Seligson's (2011) study of three cases in which police officers acted as interpreters during suspect questioning, serious flaws were found which resulted in miscommunication and conveyance of incorrect information. When a suspect facing serious legal consequences is not provided adequate representation he/she is essentially denied a voice and the outcome can prove devastating. 


\subsection{The Miranda rights}

The Miranda rights were designed to inform a suspect of the right to protect him/herself against incrimination during police interrogation (Pavlenko 2008). These rights include "(a) the right to remain silent, (b) the right to an attorney, and (c) the right to have an attorney present during questioning" (Pavlenko 2008: 3). They also inform suspects "(d) that anything they say or do can be used against them in a court of law, and (e) that if they cannot afford an attorney, an attorney will be furnished to them free of charge both prior to and during questioning" (Pavlenko 2008: 3). Various studies (Ainsworth 2008; Berk-Seligson 2000; Pavlenko 2008; Rogers, Correa, Hoersting, Shuman, Sewell, Hazelwood \& Blackwood 2008) have examined the misinterpretations of the Miranda rights by non-native speakers (NNS) of English in the US. The linguistic complexity of the Miranda rights, along with the unique cultural meaning, leads to complications in comprehension by NNS. Further difficulties may arise from the use of ad-hoc interpreters lacking adequate skills in interpreting. If the court decides that these rights were not administered properly, due to lack of an interpreter or an inadequate translation, the entire suspect testimony may be excluded from court proceedings.

Pavlenko (2008) argues for the need for a standardized translation of the Miranda rights. Similarly, Rogers et al. (2008), in their study of Miranda warning translations from different counties, found discrepancies in meaning between English and versions of the warnings translated into Spanish. These discrepancies ranged from small misinterpretations to large errors and in some cases included the outright omission of entire rights. This study also takes into account comprehension levels of suspects, both native speakers (NS) and NNS of English as well as the complexity of the translation. The findings showed that comprehension level varied considerably not only between translations but also within a single translation. Close to fifty percent of warnings contained at least one section that required a college reading level. In order to provide fairness in legal proceedings, NNS of English must be afforded Miranda warnings and other information equivalent to that provided to NS.

\subsection{Problematizing Access}

Language and cultural barriers adversely affect legal proceedings (Kahaner 2009). They lead to misinterpretations, deter non-speakers of the societal language from participating in the justice system and inhibit minority language speakers from acting as jurors. While minority speakers reserve the 
right to obtain access to interpreter services during legal proceedings, the scarcity of qualified interpreters greatly impedes the judicial process. In the United States, guidelines on court interpreting were established in 1995 by the National Center for State Courts. These guidelines recommend that all court interpreters be as highly qualified as possible and that judges should establish screening and assessment to determine qualification. It should be noted that judges' technical knowledge and expertise is on the law, not on screening interpreters or measuring interpreter's qualifications. Deciding whether an interpreter is competent or not on the basis of possessing the level of language proficiency required to interpret as well as the necessary skills to interpret requires a different type of technical expertise not possessed by the judges or the judicial system. Expertise in applied linguistics in general (for understanding language and interpreting as situated practices), on legal interpreting, and on testing and assessment is required. This expertise is found among applied linguists, not in judges.

While interpreter competency is certainly important, it is not the only concern when utilizing interpreting services within a legal setting. Limits of interpreters should be also taken into consideration. Kahaner (2009) mentions that although interpreting may not seem demanding when performed by a professional, the process is, in fact, mentally taxing. After only thirty minutes of simultaneous interpreting, even an experienced interpreter may suffer from mental fatigue (Liu 2004). This results in a decrease in quality of the interpreting performed (Moser-Mercer 2000). The Professional Standards and Ethics for California Court Interpreters recommend that two interpreters be used for any proceeding longer than thirty minutes (2013: 33).

Traditional perceptions of the interpreter's role claim that he/she should remain neutral and invisible. These perceptions simplify a reality that is complex. They imply that the interpreter is nothing more than a conduit through which information may pass (Reddy 1979, Angelelli 2004). However, this theoretical conceptualization of interpreting does not portray what professional interpreters do in practice (Rosenberg, Seller \& Leanza 2008). In reality, the interpreter is always aware of his/her presence and consequent impact in interactions. Just as any other interlocutor, interpreters also bring their own "social baggage (their beliefs, attitudes, and cultural norms)" into the encounter (Angelelli 2004) and their professional role requires them to manage those in a way that supports the achievement of communicative goals in interactions.

While discussing the challenges of administering justice across languages and cultures, in his article "Recordings, Transcripts and Translations 
as Evidence", Fishman (2006) argues that translation and interpreting (often used in courtroom in cases involving languages other than the one used by the court) are subjective activities and compares them to an art rather than a science. In translating, a statement or an utterance can have various renderings, various interpretations depending on the context in which it is used and the background of the speaker using it. Furthermore, in the issue of translating jargon used by defendants (e.g. to describe weapons or types of illegal substance) Fishman argues that no translation equivalent may exist for some colloquial expressions. Thus literal translations of them may be completely unintelligible. Fishman (2006) states that "[p]eople who engage in specialized fields tend to develop 'terms of art' and informal jargon with meanings that are a mystery to the uninitiated" (p. 498). He maintains that the proper procedure to deal with translations/interpreting of jargon involves a direct translation of these "terms of art" and then calling an expert witness to decipher the meaning. The same procedure applies for both criminal and non-criminal use of "terms of art".

\subsection{Remote Interpreting and Recorded Evidence}

Driven by recent innovations in technology and lowered costs, many government agencies increasingly resort to telephone interpreting as a means to facilitate communication between two monolingual speakers when a face-to-face interpreter is not available (Ozolins 2011). While many advances have been made in recent years, the use of telephone interpreting still poses challenges. Technical issues may affect sound quality as a result of fixed line or mobile connections and background noise. Other problems arise due to higher frequency of the use of third person by interpreters as well as confusion experienced by the minority language speaker due to a lack of information about the procedure. When the two monolingual individuals are face-to-face with the third party interpreting via speakerphone, the issue of turn taking may become a problem (Ozolins 2011, Besson et al. 2005). And perhaps, the most critical issue of all related to telephone interpreting is the fact that among companies offering telephone interpreting, contracting ad-hoc interpreters rather than professionals is the norm rather than the exception.

The use of recorded evidence in a legal setting is commonplace in US courts. Fishman (2006) offers a critique of the use of recordings, transcripts and translations as official testimony in a legal setting. The nature of recorded evidence presents many challenges, among them the quality of the recording and confirming identity of the speakers involved. In addition, unintelligibility as the result of interference by other speakers, background noise or speakers' 
accents or use of regionalisms/dialects may present an obstacle to jurors' comprehension of recorded evidence. These complications are further compounded when one or more interlocutors speak in a non-societal language.

A foreign language transcript should involve first transcribing the recording directly into the original language, followed by a translation into the societal language. Fishman (2006) posits that such a transcript falls under the classification of "expert opinion testimony". The translator must possess high proficiency in both languages in order to qualify as an expert. Inadequate translations/interpreter renditions may distort or completely change meaning and thus jeopardize the entire legal proceedings. For this reason it is of utmost importance to employ high quality, certified translators and interpreters when legal issues involve foreign language evidence and/or testimony.

\section{The Case ${ }^{1}$}

\subsection{The Site}

The US-Mexico border totals 1,954 miles and extends across the North American continent from the Gulf of Mexico in the East to the Pacific Ocean in the West. The border defines the southern boundary of the United States of America and the northern limit of Mexico. Rugged mountains and arid desert dominate the terrain that includes parts of the Rio Grande and Colorado River (International Boundary and Water Commission 2014). The busiest international land border crossing in the Western Hemisphere bisects the twin cities of San Diego, California and Tijuana, Baja California. An average of 25,000 pedestrians and 50,000 vehicles cross from Tijuana into San Diego each day (U.S. General Services Administration 2013). According to the 2010 United States Census, over 32\% of the population of San Diego County is Hispanic or Latino and 36\% of the population speaks a language other than English at home (US Census Bureau 2010). This bi-national, multicultural region creates a unique environment in which speakers of English and Spanish must interact on a daily basis as part of their normal lives.

\subsection{The Unit: Customs and Border Protection}

Policing of this bustling port of entry is the job of U.S. Customs and Border Protection (CBP). The agency's website claims that the goal of Border Security is to prevent "the entry of terrorists and their weapons", to stop "narcotics,

1. The author was appointed expert witness in this case. Permission to discuss the case publicly preserving the anonymity of parties involved was obtained. 
agricultural pests and smuggled goods from entering the country" and "identify and arrest travelers with outstanding criminal warrants". ${ }^{2}$ In fiscal year 2013, the San Diego Border Patrol employed over 2,500 agents and recorded more than 27,000 apprehensions. Of these apprehended individuals, more than $95 \%$ held Mexican citizenship (U.S. Department of Homeland Security 2014a).

Due to the high number of Spanish speakers that agents encounter, it is important that they possess the ability to communicate in Spanish if they are not using professional and qualified interpreting services. In fact, according to the Preparation Manual for the U.S. Border Patrol Entrance Examination, "[a]ll Border Patrol Agents are required to know the Spanish language" (U.S. Department of Homeland Security 2014b: 19). Currently, the CBP requires all new recruits who are proficient in Spanish to take the Spanish Language Proficiency Test. The test consists of a vocabulary section and a grammar section. The grammar portion is further subdivided into three sections containing different types of grammar questions. At the time of writing this article, no specific information was available as to the reliability and validity of this test. Those not proficient in Spanish must take the Artificial Language Test and attend a specialized eight-week Spanish training course (U.S. Department of Homeland Security 2014a; U.S. Department of Homeland Security 2014b). No information was available as to the proficiency level required for a border patrol agent to work in a language other than English.

The Spanish Language Training course for new CBP recruits consists of an occupation-based full immersion experience. It has a six-month duration. The classroom training utilizes modern task-based language teaching techniques and advanced language acquisition software. In addition to immersion within the classroom, students are housed, transported and fed in separated facilities where they are constantly exposed to the Spanish language. Recruits are only allowed to access Spanish language television programs in their dormitories and are provided with laptops equipped with Spanish training materials. Additional Spanish language books, magazines and videos are provided via a Spanish resource library (White 2006). It should be noted that research in second language acquisition has established that over four years of study are required to achieve an intermediate level of proficiency - equivalent to Bl in the Common European Framework of Reference for Languages (CEFRL) - in any language other than English. With a six-month intensive study, a person can achieve intermediate level which will allow for asking and

2. http://www.cbp.gov/xp/cgov/border_security/bs/ 2014 
answering simple questions. Furthermore, in the field of applied linguistics, it has been established that a person requires superior language proficiency (American Teachers of Foreign Language) in order to work and interact with near natives/native speakers in a variety of settings using regional varieties of language (in this specific case Mexican and US Spanish plus code switching) and a diversity of registers (low level of education and rural norm of language). The equivalent of a superior level on the ACTFL scale would be a C2 in the European framework (Degueldre 2005).

In 2008, Hispanics composed approximately $52 \%$ of the more than 18,000 U.S. border agents (U.S. Department of Homeland Security 2014b). After conducting research on US Border Agent language proficiency, no information was found on actual officer proficiency levels (U.S. Department of Homeland Security 2014a; U.S. Department of Homeland Security 2014b; U.S. General Services Administration 2013; White 2006). Thus, the number of current border patrol officers who speak Spanish and at what proficiency level is unknown. However, the data provided by the U.S. Department of Homeland Security and the U.S. General Services Administration does reveal much more information about Spanish language proficiency among new recruits. According to a 2007 testimony by the U.S. Department of Homeland Security, approximately half of all new Border Patrol recruits are Spanish speakers (Stana 2007), although no reference is made to either their degree of education in Spanish or their English proficiency. This means that half of all agents recruited to serve as border agents do not speak Spanish and must complete the mandatory Spanish-language training course in order to achieve proficiency.

Over thirty years ago, a report from the National Commission for Excellence in Education states that "achieving proficiency in a foreign language ordinarily requires from 4-6 years of study" (1983: 124). According to the American Council on the Teaching of Foreign Languages (ACTFL), 240 hours of full-time immersion training in Spanish results in Intermediate Low proficiency (Language Testing International 2014). At this level, speakers are able to communicate using simple language "to complete uncomplicated communicative tasks" (Swender et al 2012: 8) with some hesitation and frequent inaccuracies and misunderstandings. Even interlocutors who frequently interact with non-native speakers may experience difficulties in comprehension when interacting with Intermediate Low Spanish speakers. In his testimony before the US House of Representatives Committee on Homeland Security, Stana (2007) states that the Border Patrol requires only 214 hours in the Spanish language classroom. Applying ACTFL's proficiency estimates, 
officers do not reach the Intermediate Low (B1 in the Common European Framework) rating after completion of training. Thus, when interacting primarily with Spanish-speaking suspects, communication is limited and frequent misunderstandings occur.

\subsection{The Participants}

The interpreted communicative event, which is the focus of this research, includes four participants. Two agents of the US Customs and Border Patrol - Special Agent 1 and Special Agent 2 - conducted the questioning. Both were American middle-aged monolingual English speakers. The Detainee (José3) was a younger monolingual Spanish-speaking male from Mexico. He has worked as driver over the US/Mexico border for the last four years. The fourth participant was the bilingual interpreter, Marina, a female born in Mexico who participated via speakerphone and interpreted between the English- and Spanish-speaking monolingual parties. Her credentials ${ }^{4}$ included a personal statement about her years of experience (8) in working for the telephone company as an interpreter. Marina works for the largest provider of telephone interpreting services in the world. It is utilized by US Customs and Border Protection in situations where no interpreter is available on site.

\subsection{The Data}

The interrogation interview of the Detainee by the Special Agents and the official transcription/translation performed by the court constitutes the data for analysis. The Spanish/English interpreter-mediated interview was video recorded, put onto DVD and the audio was transcribed not verbatim (see comment on transcript between lines 4 and 5 below in Section 3.4.2). The Spanish used during the interview both by the detainee and the interpreter was translated into English by a translator/transcriber appointed by the court. ${ }^{5}$ Thus, the official transcription (and the only one used for the trial) is entirely in English.

3. All names used are pseudonyms to protect participants' identity.

4. As part of the appeal process the interpreter's qualifications and renditions were studied. The interpreter was summoned to produce evidence of her qualifications. At the time no degree or certification was produced. Only a personal statement stating her name and last name and the years of experience in working for the telephone company.

5. Given the space constraints, a discussion on the complete discourse analysis of the whole transcription based on the DVD and a comparative and contrastive analysis between the transcript and the official case transcript is beyond the scope of this article. 


\subsubsection{The Story as told by the DVD}

The officers are in a trailer trying to conference in the interpreter (Marina) before the detainee (José) arrives. They experience technical difficulties when trying to reach the interpreter via telephone and put her on speakerphone. Eventually, they are able to connect and the interpreter enters the interaction via speakerphone. The officers and the interpreter are ready waiting for José. As José enters the room he is asked to sit by the phone but he is not explained that there is an interpreter who will facilitate communication remotely. The special agents want to explain the detainee his rights. In English they tell the interpreter to instruct him to read off a list of rights and to write his initials next to each one to indicate he has understood. Because José did not know that there would be interpreting rendered over the speakerphone and because the agents do not introduce the interpreter and start speaking English, José waives his hands and states "no entiendo, no hablo inglés" (I do not understand. I do not speak English) assuming that they would continue to communicate face-to-face in English. Further confusion occurs because the interpreter did not explain to the detainee what he needed to do (write his initials by each line of the Miranda rights). So José signs his name instead of simply writing his initials. The special agents notice his mistakes (which undermines José's credibility) and call the attention of the interpreter. The interpreter never explained that she had not conveyed the procedure to the detainee, therefore José did not know that he was supposed to initialize after each line was read to him. This, however, is rectified through the interpreter. Once José has finished reading each of his rights, he is asked to sign a waiver.

Next, the agents ask the detainee to explain his version of the events. José explains that he had spoken with a customs officer named Rodrigo, right at the border, the week prior, after learning that his employers were planning to have him transport illegal substance across the international border. Rodrigo had informed José that upon entering customs with the vehicle containing narcotics, customs agents would assist him. The detainee explains that he had not been in communication with his employers or had access to the truck, the "tunkie", throughout the previous week. A major breakdown in communication occurs when the interpreter fails to understand the meaning of "tunkie". After much back and forth trying to ascertain what tunkie is, who tunkie is, the officers assume that "Tunkie" or "Tookie" is the name of one of the detainee's employers and the meaning is never clarified. José repeats "the tunkee", "tunkee", as he pretends he is holding the wheel of a truck 
and driving. The interpreter who is on the other end of the speakerphone cannot see the gesture and the special agents pay no attention to Josés body language. They continue to ask about Tunkee, where he lives, how many trucks he owns, etc. In their minds, Tunkee is Jose's handler. José continues by explaining that he received a call via radio from Mario (not Tunkee!), the owner of the truck (and handler), in the morning instructing him to meet them at a convenience store in order to be transported to the truck waiting in line at the border crossing. José states that he waited in line for half an hour before he passed through customs and was sent to the ramp. Another communication breakdown occurs when the interpreter fails to understand the meaning of "rampa" (ramp). The agents assert that the detainee did not declare he was transporting drugs when he crossed the border. They ask why he did not contact Rodrigo, the border patrol officer, before arriving to customs. They ask him if he had a phone with him. José replies that he had already contacted Rodrigo the week before when he learnt his employer was going to ask him to transport substance and he came asking for protection. Rodrigo told José to come straight to him when he crossed. Because José was sent to ramp for inspection immediately, José believed Rodrigo was acting according to what they had discussed the week before. This message was never interpreted for the special agents. When asked why José had not communicated with Rodrigo that same day, José says he did not have a balance ("saldo") on his mobile phone. The interpreter does not understand the term "saldo" (balance on the mobile phone pre-paid card) and misinterprets this as not having enough money to call from his phone (this, once again, undermines the credibility of the detainee as he had a twenty-dollar note which was put with his belongings as he started the interview). José explains that he arrived at the line for border crossing at approximately 10:00 a.m. and upon entering, waited approximately two hours for the customs officers to check the truck. The Agents ask what happened during this time and state that the narcotics were found when a police canine unit detected the scent of drugs in the truck. The Agents ask if the Detainee knew he was transporting illegal drugs. The interpreter interprets the question: "Did you know, when you were driving to the United States, that you were going to cross the international border with illegal substance?" as a statement: but, you did know you were transporting illegal drugs ("usted sí sabía que estaba cruzando droga"). The detainee asked a clarification question to that statement: if I knew...? ("Si sabía?") (Note that in Spanish si [without accent] means if and sí [with accent] means yes. Josés utterance had a rising tone. He was asking a question: "if I knew?" ("si sabía?). The interpreter conveyed a statement instead 
of a question and stated: "sí, sabia" (yes, I knew) with the intonation of an affirmative statement.

The agents proceed to ask how much the Detainee was to be paid, where he was to take the truck after crossing the border and where his handler lives. The Detainee informs the Agents that he was to be paid three thousand US dollars after returning to Mexico, the truck was to be driven to just outside of Los Angeles and gives them the street name where his handler lives in Mexico. Special Agent 2 asks how the detainee was going to drive from the border to Los Angeles as the truck was missing half of its gears and Special Agent 1 asks how fast he could go on the highway. The interpreter ignores the first question about gears and only asks how fast could he drive and if he did drive on the highway. José states that he never drove on the highway because he went straight to customs. The agents declare that they have finished questioning and inform the detainee that he is to be photographed, fingerprinted and booked into the local jail to await a court date with the judge.

\subsubsection{The story as told by the transcript (based only on interpreter's renditions $\left.s^{6}\right)$}

The next few segments are only a few examples selected from the official translation/transcription. They illustrate instances in which what transpired in the actual interview is not reflected in the transcript. Segment 1 is the beginning of the interpreted communicative event (Angelelli 2000) in a trailer on the San Diego/Tijuana Border. The three parties present are the two special agents (Special Agent 1 and 2) and the detainee (José). The interpreter, Marina, is accessing the communicative event remotely via a speakerphone.

The participants' names are abbreviated as follows: SAl (Special Agent 1); SA2 (Special Agent 2); INT (Interpreter) and DTE (Detainee).

6. In the US Court system English is the official language of the court. Therefore transcribers record only utterances in English. There is thus no written record of the original utterances of speakers in their native languages. The record only shows the utterances of the interpreter into English. In this specific case, the video/audio was sent to a translator/transcriber who decided not to transcribe the interaction between the two special agents and the interpreter when they were getting ready for the call (see page 11-12). The segments presented in this article are copied from the official transcript. 


\section{Segment 1}

\begin{tabular}{|c|c|l|}
\hline 1 & SA1 & $\begin{array}{l}\text { Can you hear me? Can you hear me? Ok, we're trying to figure out why } \\
\text { this thing doesn't want to work. Are you there? Hang on; we're trying to } \\
\text { make the speaker part work. Can you hear me now? Ok, can you hear me } \\
\text { again? Can you hear me? Ok, let's see. }\end{array}$ \\
\hline 2 & SA2 & Hold it and hang up for a sec. \\
\hline 3 & SA1 & This button? \\
\hline 4 & SA2 & I don't know. \\
\hline & & $\begin{array}{l}\text { (TRANSLATOR'S NOTE: This goes on for several minutes while the agents } \\
\text { prepare for the interview; will resume transcription/translation when } \\
\text { interview of client begins). }\end{array}$ \\
\hline 5 & SA2 & Ok, have a seat. \\
\hline 6 & SA1 & Ok, Marina? \\
\hline 7 & INT & Yes, I'm here. \\
\hline 8 & SA1 & $\begin{array}{l}\text { Ok, we are here with José Leiva Marquez and we want to talk with him } \\
\text { about a couple of things; but first, can you just explain to him that we want } \\
\text { to advise him of his rights? }\end{array}$ \\
\hline 9 & INT & The thing is, we are going to indicate to you your rights. \\
\hline 10 & SA1 & What did you say? \\
\hline 11 & DTE & I don't understand English. \\
\hline 12 & SA1 & Say it out loud, louder so she can hear. \\
\hline 13 & DTE & What? \\
\hline 14 & SA1 & Tell him to speak louder into the phone. \\
\hline 15 & INT & Speak louder so I can hear you sir; can you hear me? \\
\hline 16 & DTE & I can hear you now, I'm listening now. \\
\hline
\end{tabular}

The technological challenges faced by the special agents when they conference in the interpreter are noted by the transcriber between turns 4 and 5 (Translator's note). On the DVD this goes on for over 3 minutes during which the special agents and the interpreter have the opportunity to interact, discuss the quality of sound, etc. as well as the interview they are about to conduct. This positions the interpreter as part of a team, hired by the Border Patrol to help them communicate with José, the detainee. During the time they are waiting for the detainee (José) to be brought in, the agents ask the interpreter if she knows the Miranda rights that she will be interpreting. She replied that she is familiar with them and is looking for them. She does not have the official translation of them. All of this is captured on the DVD but, as evident above, is not part of the official transcript. 


\section{Segment 2}

The following segment of the transcript illustrates the communication on the Miranda rights. The segment starts when José comes in and wants to explain his story. He is told to follow procedure.

\begin{tabular}{|l|l|l|}
\hline 21 & SA2 & $\begin{array}{l}\text { Ok, tell them that we'll get to that in a second but right now we want to } \\
\text { make sure that he understands his rights. }\end{array}$ \\
\hline 22 & INT & $\begin{array}{l}\text { Ok, we're going to get to that point later on but right now we want you } \\
\text { to understand your rights because this is an official action we have to do } \\
\text { prior. }\end{array}$ \\
\hline 23 & SA2 & $\begin{array}{l}\text { Ok, ask him to read each one of these out loud and if he understands } \\
\text { it to go ahead and initial next to the one he just read and if he doesn't } \\
\text { understand something to just ask questions. }\end{array}$ \\
\hline 24 & INT & $\begin{array}{l}\text { Ok, read each one of your things out loud and if there is any one you don't } \\
\text { understand say so, and at the end sign it when you understand everything. }\end{array}$ \\
\hline 25 & DTE & You have the right [ \\
\hline 26 & INT & \multicolumn{1}{c|}{ [Do you know how to read? } \\
\hline 27 & DTE & Yes, you have... [ \\
\hline 28 & INT & \multicolumn{1}{c|}{ [Ok, read it } \\
\hline 29 & DTE & The right to remain silent, number one. \\
\hline 30 & INT & Uh huh \\
\hline 31 & SA2 & Do you understand that? \\
\hline 32 & DTE & Yes. \\
\hline 33 & INT & (Unintelligible) \\
\hline 34 & SA2 & Ok, put your initials right here. \\
\hline 35 & INT & Initials there. \\
\hline 36 & DTE & One, number two says. \\
\hline 37 & SA2 & No, no, no, your initials. \\
\hline 38 & SA1 & Initials. \\
\hline 39 & INT & Initials. \\
\hline 40 & DTE & Oh, my initials. \\
\hline
\end{tabular}

On turn 23 Special Agent 2 explains to Marina, the interpreter, that José needs to read each one of the Miranda rights and write his initials at the end of each as he reads them out loud to show he understands them (or he should ask questions if he does not understand them), and to sign his name at the end. The interpreter conveys this information differently on turn 24 , as she directs José to read each one of the Miranda rights, state what he does not understand and sign. This difference causes misunderstandings and undermines the credibility of José. His behavior is portrayed as unable to follow instructions and 
comply (initialize at the end of each rather than only signing at the end) or understand Spanish (initials should be translated as "sus iniciales"). José starts reading on turn 25. Marina interrupts him to ask if he knows how to read and directs him to continue. This interruption was unnecessary. Had the interpreter been actively listening to Josés readings, turns 25-28 would have been about each of the Miranda right rather than about Josés reading ability.

\section{Segment 3}

In this segment José begins to tell his story. He states how he voluntarily crossed the border as soon as he became aware that his handler was going to have the truck "cargado" (loaded). He has learnt that his handler was going to place illegal substance into the truck without telling José when that would happen or where in the truck the substance would be placed.

\begin{tabular}{|l|l|l|}
\hline 71 & DTE & $\begin{array}{l}\text { Last week I came and commented to the officers about what they wanted } \\
\text { me to cross, with them here and they called someone from Customs whose } \\
\text { name is, I don't remember. }\end{array}$ \\
\hline 72 & INT & $\begin{array}{l}\text { Last week I made a comment to an officer, what was happening and I } \\
\text { talked with somebody from Customs; the name. }\end{array}$ \\
\hline 73 & SA2 & Ok what, who did he talk to? \\
\hline 74 & INT & With whom did you talk to? \\
\hline 75 & DTE & $\begin{array}{l}\text { I gave the paper with the name to the officers that detained me because he } \\
\text { told me when, because last week I asked them to search my truck because } \\
\text { they were thinking of crossing that and they told me that when I crossed } \\
\text { again and they found whatever I had, to call him, the one I had spoken } \\
\text { with. }\end{array}$ \\
\hline 76 & INT & $\begin{array}{l}\text { I told them that this would happen and they told me if I was going to cross } \\
\text { again and they would find something I would have to talk with them. }\end{array}$ \\
\hline 77 & SA2 & Ok, who did he talk to though? \\
\hline 78 & INT & With whom did you talk? \\
\hline 79 & DTE & The officer who helped me is named Denaldo Chys, something like that. \\
\hline 80 & INT & What is his name? \\
\hline 81 & DTE & Denaldo Chys, Chys, his last name was something like that. \\
\hline 82 & INT & Reinaldo Chys? \\
\hline 83 & DTE & Yes, something like that, a Customs officer. \\
\hline 84 & SA2 & Ok. \\
\hline 85 & INT & He's a Customs officer. \\
\hline 86 & SA2 & Yeah, ok, I talked to him. \\
\hline
\end{tabular}


José came to the Border Patrol agents to alert them of his situation, and to seek help and protection. He spoke to an agent (a customs officer) whose name he could not remember exactly but had written down on a piece of paper that was taken from him with his belongings as he was arrested. José explains this in turn 71. This information is not conveyed to the special agents. The special agents need to know exactly to whom José talked. This information is important to them. It is asked on turn 72 and answered on turn 75 a second time, but is not interpreted. It is important to note that the interpreter misses several segments of key information undermining, once again, the detainee's credibility. The detainee tried to answer the question on the agent's name on turns $71,75,79,81$ and 83 . The interpreter conveyed a similar name on turn 82 and clarified that he was a customs officer on turn 85 .

\section{Segment 4}

The misunderstandings magnify as the interpreter does not hear what José states and, if she does, at times she appears not to understand what José is explaining.

\begin{tabular}{|c|c|c|}
\hline 101 & SA2 & $\begin{array}{l}\text { Ok, so if you do something and you don't let us know ahead of time and } \\
\text { we're not a part of what's going on, then you're on your own. }\end{array}$ \\
\hline 102 & INT & $\begin{array}{l}\text { If you do something and you don't tell us before hand what you're going } \\
\text { to do, then you are on your own. }\end{array}$ \\
\hline 103 & SA2 & Ok. \\
\hline 104 & DTE & $\begin{array}{l}\text { Yes but I had spoken with him and I had commented that they had taken } \\
\text { the truck away from me and I hadn't worked all week and I left the truck } \\
\text { parked at their home and they didn't ask me to cross until today and that } \\
\text { was what I... }\end{array}$ \\
\hline 105 & INT & $\begin{array}{l}\text { Speak slower because I don't understand you. (Unintelligible) Repeat } \\
\text { what you said because I didn't understand anything for the translation; } \\
\text { I'm translating. He's going to repeat what he's trying to say. }\end{array}$ \\
\hline 106 & SA2 & Ok. \\
\hline 107 & DTE & I'm telling you that last week when I spoke with him. \\
\hline 108 & INT & Last week I talked with him. And? \\
\hline 109 & DTE & $\begin{array}{l}\text { And I'm telling you that I hadn't worked all that week, since I had told } \\
\text { him, until today. I had left everything at their home; everything. }\end{array}$ \\
\hline 110 & INT & I had left everything in his house, till then. \\
\hline 111 & SA2 & You left every, what did you leave at whose house? \\
\hline 112 & INT & What did you leave and at whose house? \\
\hline 113 & DTE & $\begin{array}{l}\text { The person in charge of the truck; I left it with him. He stayed at his } \\
\text { house with the truck. And then... [ }\end{array}$ \\
\hline
\end{tabular}




\begin{tabular}{|c|c|c|}
\hline 114 & INT & $\begin{array}{l}\text { [The one that is in charge of the truck; everything was left at his } \\
\text { house with the truck. }\end{array}$ \\
\hline 115 & SA2 & I don't understand what he's saying; I don't understand. \\
\hline 116 & INT & $\begin{array}{l}\text { I don't understand what he is saying either; let's see, explain it to me } \\
\text { again. }\end{array}$ \\
\hline 117 & DTE & The "Tunkee", the tractor, or "Tunkee". \\
\hline 118 & INT & The how much? \\
\hline 119 & DTE & The truck, the big car, the "Tunkee" "Tookie". \\
\hline 120 & SAl & Tookie? \\
\hline 121 & DTE & Yes, Tookie, the car, the tractor, the tractor. \\
\hline 122 & SAl & Is that a person? \\
\hline 123 & SA2 & What is Tookie; do you know what that is Marina? \\
\hline 124 & INT & No, what is Tookie? \\
\hline 125 & SAl & Name of Tookie? \\
\hline 126 & DTE & Yes, the car, the big one, I left it at his house. \\
\hline 127 & SA2 & Tookie's house. \\
\hline 128 & INT & The big car that is at his house. \\
\hline 129 & SAl & Tookie is the name, is the man that owns the truck. \\
\hline 130 & SA2 & $\begin{array}{l}\text { Ok, so Tookie owns the truck you were driving today? Ok, let's start with } \\
\text { today; what did you do today? }\end{array}$ \\
\hline 131 & INT & What did you do today? Let's start with today; what did you do? \\
\hline 132 & DTE & $\begin{array}{l}\text { Nothing, I spent the day at home; that's where I spent all week. In fact, } \\
\text { I didn't cross because everything had remained there and I just stayed at } \\
\text { home. }\end{array}$ \\
\hline
\end{tabular}

Marina misses several key pieces of information. Josés frustration for not being understood is evident since turn 104. Marina cannot keep up with José's speed or accent (105). Because the interpreter cannot access body language, she cannot see José's gestures when he is pretending to drive a truck, moving his arms from left to right in a semi-circle as if he were holding a wheel. The special agents pay no attention to his body language as he repeats el tunkee, el tookie. Marina follows the special agents' understanding of the situation. Together with Marina, the agents construed tunki as the name of the owner of the truck. More than twenty turns were used to create more confusion. José could not get his message across and the agents could not get a straight answer. Marina was unable to interpret or facilitate communication. Instead her intervention contributed to the confusion and misunderstanding. 


\section{Segment 5}

Almost thirty minutes into the interview and over a hundred and fifty turns of talk the special agents are still seeking the answer to a yes/no question: did Jose know he was carrying narcotics when he was crossing the international border? For the same amount of time José has been trying to explain that he had arranged with the customs officer that he would come directly to see him as custom officers were going to handle the issue. During all this time the interpreter, who supposedly was hired to help the parties communicate with each other, hindered understanding resulting in frustration, loss of time and unsound decisions. In this last segment, which precedes the conclusion of the interview, we see one more example of how, in a linguistically diverse encounter, the lofty dream of justice for all is severely challenged.

\begin{tabular}{|c|c|l|}
\hline 151 & SA2 & $\begin{array}{l}\text { Ok, so you knew what you were doing today, that you were driving a } \\
\text { truck filled with narcotics and you were attempting to come into the } \\
\text { United States. }\end{array}$ \\
\hline 152 & INT & $\begin{array}{l}\text { You knew you were driving the truck and it had drugs and you were } \\
\text { attempting to cross the border into the United States. }\end{array}$ \\
\hline 153 & DTE & Yes, we had commented that; I with the officer last week, that if \\
\hline 154 & INT & [What? \\
\hline 155 & DTE & $\begin{array}{l}\text { [that if I knew something, to let them know but } \\
\text { I wasn't told anything all week. In fact, I was at my home all week and } \\
\text { today was when they told me and I came straight here so they could check } \\
\text { it here and he told me that when they caught it here they would take } \\
\text { charge of that. }\end{array}$ \\
\hline 156 & INT & $\begin{array}{l}\text { Ok, they didn't call me the whole week; they called me today to pick up } \\
\text { the truck and that's when I came and I knew that I was coming with it and } \\
\text { that's when I thought that they were going to be in charge of that. }\end{array}$ \\
\hline
\end{tabular}

On turn 151 Special Agent 2 tries, once again, to ascertain that José was aware of his actions: that he was driving a truck carrying narcotics while attempting to enter the United States. The special agents need to establish intention. The interpreter repeats Special Agent 2's statement and José starts to repeat the story he has been telling from the beginning of the interview. As soon as he learnt the handler would try to load the truck, he came to report it. Then he was home all week and the day he was asked to cross he went directly as previously discussed with Rodrigo (the custom agent). José claims not to have known anything about carrying narcotics until he was pulled and asked to go to ramp for inspection. He finishes stating this again on turn 155. He is interrupted by the interpreter (turn 154), who, once again, does not hear well. 


\section{Conclusion}

The case discussed in this article is one example of the many interpreted communicative events that occur daily in the United States Customs Office on the international border. This border crossing point, while extremely busy, is only one among many crossings between the United States and Mexico. The situation described here is not an exception. There are monolingual agents that need to communicate with monolingual speakers of languages other than English (mostly Spanish). There are no dedicated professional interpreters to serve the communicative needs of this federal office. The agents are told that when they need interpreting services they have to call a company that provides this service remotely. When recruiting interpreters, companies providing over-the-phone interpreting services seem to focus more on the bottom line than on the quality of the service offered. The interpreter used by the telephone company in this case is not a certified legal/court interpreter. The interpreter's experience (language proficiency and years of experience in interpreting) are taken at face value. The law establishes that the judges are responsible for appointing and screening legal/court interpreters. As previously established, judges do not have expertise to do this. Given the limitations that current judicial systems have in serving the needs of their linguistically-diverse populations, cases like this one call into question the very nature of the goals of "access to Justice" and ultimately "justice for all".

This preliminary exploratory study aims to call attention to the many challenges faced while trying (or not trying) to reach this goal. Although one official transcript and one observation of an encounter may not be representative of the way the US Custom Office conducts business, and although deeper analysis of the official transcript and the DVD (which are beyond the scope of the article but were conducted at the time the author was appointed to offer expert witness testimony) reveal further issues, one fact cannot be denied: access to justice was hindered. This situation is not uncommon not just in border areas and not only in the United States. In contemporary societies (beyond border areas), multilingualism is the norm rather than the exception. And, unfortunately, challenges in providing access to justice to linguistic minorities are not unfrequent. From quality to availability, from cost of provision to matching language combinations, judicial systems are not always in a position to meet the communicative needs of all people, so that access to justice becomes real. This is especially true for those unable to speak the language of the court. If our goal as a society is "justice for all", more attention needs to be paid to the ways in which all human beings have (or do not have) access to it. Linguistic diversity and quality interpreting cannot be ignored. 


\section{Bibliography}

AinSWORTH, Janet. (2008) 'YYou have the right to remain silent...' but only if you ask for it just so: the role of linguistic ideology in American police interrogation law." The International Journal of Speech, Language and the Law 15:1, pp. 1-23.

ANGELELLI, Claudia. (2000) "Interpretation as a communicative event: A look through Hymes' lenses." Meta 45:4, pp. 580-592. Electronic version available at: <http://erudit.org/revue/meta/2000/v45/n4/001891ar.pdf>

ANGELELLI, Claudia. (2004) Revisiting the interpreter's role: A study of conference, court and medical interpreters in Canada, Mexico, and in the United States. Amsterdam/Philadelphia: John Benjamins.

Berk-Seligson, Susan. (2000) "Interpreting for the police: Issues in pre-trial phases of the judicial process." Forensic Linguistics 7:2, pp. 212-237.

BERK-SELIGSON, Susan. (2011) "Negotiation and communicative accommodation in bilingual police interrogations: a critical interactional sociolinguistic perspective." International Journal of the Sociology of Language 207, pp. 29-58.

BESSON, Chantal; Daria Graf; Insa Hartung; Barbara Kropfhäusser \& Séverine Voisard. (2005) "The importance of non-verbal communication in professional interpretation." International Association of Conference Interpreters. Electronic version available at: <http://aiic.net/page/1662/the-importance-of-non-verbal-communication-in-professional-interpretation/ lang/l>

DEGUELDRE, Christian. (2005) "Determining language proficiency levels for language professionals: issues and challenges for translators and interpreters in the United States." Forum 3:1, pp. 67-93.

Fishman, Clifford S. (2006) "Recordings, transcripts, and translations as evidence." Washington Law Review 81:3, pp. 437-523.

HAMEL, Rainer Enrique. (1995) "Derechos lingüísticos como derechos humanos: debates y perspectivas." Alteridades 5:10, pp. 11-23.

HYMES, Dell H. (1974) Foundations in sociolinguistics: An ethnographic approach. Philadelphia: University of Pennsylvania Press.

KAHANER, Steven M. (2009) "The administration of justice in a multilingual society - open to interpretation or lost in translation?" Judicature 92:5, pp. 224-231.

LiU, Minhua. (2004) "Working Memory and Expertise in Simultaneous Interpreting." Interpreting 6:1, pp. 19-42.

MOSER-MERCER, Barbara. (2000) "Simultaneous Interpreting: Cognitive Potential and Limitations." Interpreting 5:2, pp. 83-94. 
OzOLINS, Uldis. (2001) "Telephone interpreting: Understanding practice and identifying research needs." The International Journal for Translation \& Interpreting Research 3:1, pp. 33-47.

PAVlENKO, Aneta. (2008). "I'm very not about the law part': Nonnative speakers of English and the Miranda warnings." TESOL Quarterly 42:1, pp. 1-30.

REDDY, Michael J. (1979) "The Conduit Metaphor: A Case of Frame Conflict in our Language about Language." In: Ortony, Andrew. (ed.) 1979. Metaphor and Thought. Cambridge: Cambridge University Press, pp. 284-324.

Rogers, R.; A. Correa; R. Hoersting; D. Shuman; K. Sewell; L. Hazelwood \& H. Blackwood. (2008) "Spanish Translations of Miranda Warnings and the Totality of the Circumstances." Law and Human Behavior 33, pp. 61-69.

RosenberG, Ellen; Robbyn Seller \& Yvan Leanza. (2008) "Through interpreters' eyes: comparing roles of professional and family interpreters." Patient Education and Counseling 80: 87-93. DOI: 10.1016/j.pec.2007.09.015

StanA, Richard M. (2007) Border Patrol: Costs and Challenges Related to Training New Agents. Testimony Before the Subcommittee on Management, Investigations, and Oversight, Committee on Homeland Security, House of Representatives. Washington: U.S. Govt. Accountability Office.

Swender, E.; D. J. Conrad \& R. Vicars. (2012) ACTFL Proficiency Guidelines. Alexandria: ACTFL, Inc.

VAN Dijk, Teun. (2000) "Discourse and access." In: Phillipson, R. (ed.) 2000. Rights to language: equity, power and education. New York: Lawrence Earlbaum Associates, pp. 73-78.

VARIOUS AUTHORS (Language Testing International). (2014) Understanding Proficiency with LTI. Electronic version available at: <http://www.languagetesting. com/how-long-does-it-take>

VARIOUS AUTHORS (National Commission on Excellence in Education). (1983) "A Nation at Risk: The Imperative for Educational Reform." The Elementary School Journal 84:2, pp. 112-130.

VArious Authors. (2013) Professional Standards and Ethics for California Court Interpreters (Fifth Edition). Electronic version available at: <http://www. courts.ca.gov/documents/CIP-Ethics-Manual.pdf>

VARIOUS AUTHORS (United States Census Bureau). (2010) State \& county quickfacts. Electronic version available at: <http://quickfacts.census.gov/qfd/ states/06000.html>

VARIOUS AUTHORS (U.S. Department of Homeland Security). (2014a) U.S. Border Patrol Fiscal Year 2013 Statistics. Electronic version available at: <http:// www.cbp.gov/xp/cgov/border_security/border_patrol/usbp_statistics/ usbp_fy13_stats/>

VARIOUS AUTHORS (U.S. Department of Homeland Security). (2014b) Preparation Manual for the U.S. Border Patrol Entrance Examination. Electronic version 
available at: <http://www.cbp.gov/linkhandler/cgov/careers/study_guides/ guides_bp/entry_guide/bp_entrance_exam.ctt/prep1896.pdf>

VARIOUS AUTHORS (U.S. General Services Administration). (2013) San Ysidro Land

Port of Entry Fact Sheet. Electronic version available at: <http://www.gsa.gov/ portal/category/105703>

White, R. (2006) Aqui se habla Espanol: Officers learn basics of Spanish catered to job. Electronic version available at: <http://www.cbp.gov/xp/CustomsToday/2006/april/officers_learn_spanish.xml>

\section{BIONOTE / NOTA BIOGRÁFICA}

Professor Claudia V. Angelelli is Chair in Multilingualism and Communication at Heriot-Watt University, UK, and Professor Emerita of Spanish Linguistics at San Diego State University, US. Her research lies at the intersection of sociolinguistics, applied linguistics and translation and interpreting studies. She is the author of Medical Interpreting and Cross-cultural Communication (Cambridge University Press), and Revisiting the Role of the Interpreter (John Benjamins) and co-editor of Researching Translation and Interpreting (Routledge, forthcoming) and Testing and Assessment in Translation and Interpreting Studies (John Benjamins). She has served as Guest Editor of The International Journal of the Sociology of Language (Translators and Interpreters: Geographic Displacement and Linguistic Consequences), Translation and Interpreting Studies (The Sociological Turn in Translation and Interpreting) and Cuadernos de ALDEEU (Minding the Gaps: Translation and Interpreting Studies in Academia). Her work appears in The Annual Review of Applied Linguistics, The Critical Link, Cuadernos de ALDEEU; Interpreting, Meta, MonTI (Monografias de Traducción e Interpretación), The Translator, TIS (Translation and Interpreting Studies), The International Journal of the Sociology of Language and numerous edited volumes. Prof. Angelelli is the President of the American Translation and Interpreting Studies Association and has served as Director of the Consortium of Distinguished Language Centers and the American Translators Association. Currently she is the World Project Leader for ISO Standards on Community Interpreting.

Claudia V. Angelelli es catedrática en Multilingüismo y Comunicación en Heriot-Watt University (Edimburgo, Reino Unido) y profesora emérita de Lingüística Española en San Diego State University (Estados Unidos). Su investigación se sitúa en el cruce entre sociolingüística, lingüística aplicada y estudios de traducción e interpretación. Es autora de Medical Interpreting and 
Cross-cultural Communication (Cambridge University Press), y Revisiting the Role of the Interpreter (John Benjamins); coeditora de Researching Translation and Interpreting (Routledge, en prensa) y Testing and Assessment in Translation and Interpreting Studies (John Benjamins). Ha sido editora invitada de The International Journal of the Sociology of Language (Translators and Interpreters: Geographic Displacement and Linguistic Consequences), Translation and Interpreting Studies (The Sociological Turn in Translation and Interpreting) y Cuadernos de ALDEEU (Minding the Gaps: Translation and Interpreting Studies in Academia). Publica habitualmente en revistas como The Annual Review of Applied Linguistics, The Critical Link, Cuadernos de ALDEEU; Interpreting, Meta, MonTI (Monografias de Traducción e Interpretación), The Translator, TIS (Translation and Interpreting Studies), The International Journal of the Sociology of Language y en numerosos volúmenes colectivos. Claudia Angelelli es presidenta de la American Translation and Interpreting Studies Association (ATISA) y ha sido directora del Consortium of Distinguished Language Centers y de la American Translators Association (ATA). Actualmente es líder mundial del proyecto que desarrolla la norma ISO sobre Interpretación en los Servicios Públicos. 